\title{
GMR
}

\section{Antifungal activity, yield, and composition of Ocimum gratissimum essential oil}

\author{
F.B.M. Mohr ${ }^{1}$, C. Lermen ${ }^{1}$, Z.C. Gazim ${ }^{1}$, J.E. Gonçalves ${ }^{2,3}$ and O. Alberton ${ }^{1}$ \\ ${ }^{1}$ Programa de Pós-Graduação em Biotecnologia Aplicada à Agricultura, \\ Universidade Paranaense, Umuarama, PR, Brasil \\ ${ }^{2}$ Programa de Pós-Graduação em Tecnologia Limpas e em Promoção da Saúde, \\ UniCesumar, Maringá, PR, Brasil \\ ${ }^{3}$ Instituto Cesumar de Ciência, Tecnologia e Inovação, Maringá, PR, Brasil \\ Corresponding author: O. Alberton \\ E-mail: odair@unipar.br / oalberton@yahoo.com.br \\ Genet. Mol. Res. 16 (1): gmr16019542 \\ Received November 18, 2016 \\ Accepted December 19, 2016 \\ Published March 16, 2017 \\ DOI http://dx.doi.org/10.4238/gmr16019542
}

Copyright (C) 2017 The Authors. This is an open-access article distributed under the terms of the Creative Commons Attribution ShareAlike (CC BY-SA) 4.0 License.

\begin{abstract}
Ocimum gratissimum L. or clove basil, belongs to the Lamiaceae family, has various desirable uses and applications. Beyond its aromatic, seasoning, and medicinal applications, this plant also has antimicrobial activity. This study was aimed at assessing the antifungal activity, yield, and composition of the essential oil (EO) of $O$. gratissimum. The species was cultivated in garden beds with dystrophic red latosol soil type containing high organic-matter content. The EO was obtained by hydrodistillation of dried leaves in a modified Clevenger apparatus, followed by determination of its content. Chemical characterization was carried out by gas chromatographymass spectrometry (GC-MS). Microbial activity was assessed using the broth microdilution method, by determining the minimum inhibitory concentration (MIC), in order to compare the antimicrobial effect of $\mathrm{EO}$ in 10 isolates-Fusarium oxysporum f. sp tracheiphilum (CMM0033), F. oxysporum f. sp. cubense (CMM-0813 and CMM-2819), F. oxysporum f. sp lycopersici (CMM-1104), F. solani (CMM-3828),
\end{abstract}

Genetics and Molecular Research 16 (1): gmr16019542 
Rhizoctonia solani (CMM-3274), and Macrophomina phaseolina (CMM-2715, CMM-3875, CMM-3615, and CMM-3650). The EO was a highly effective inhibitor of the studied phytopathogenic fungi, with MICs varying from 31.25 to $125 \mu \mathrm{g} / \mathrm{mL}$. F. oxysporum f. sp lycopersici and $R$. solani were the most sensitive; both were inhibited at an MIC of $31.25 \mu \mathrm{g} / \mathrm{mL}$. The EO content in the plant extract was $0.18 \%$. Thirty chemical compounds were detected via GC-MS, with linalool $(32.9 \%)$ being the major compound followed by 1,8-cineole (21.9\%), both oxygenated monoterpenes. It can be concluded that clove basil EO is a highly effective antifungal agent, and therefore, a potential alternative for the control of plant pathogenic diseases.

Key words: Antifungal agent; Basil; Linalool; Medicinal plants; Plant pathogens

\section{INTRODUCTION}

Phytopathogenic fungi can decrease crop yield as their reproductive structures allow them to spread across large cultivated areas very quickly. These structures are the spores disseminated by wind, soil, and water, which can infect a large number of plants. Unfavorable germination conditions cause spore latency for extended periods. After infection and growth, the fungi can produce enzymes and toxins that damage plant structures, causing metabolic imbalance, and consequently, a decreased yield or even total crop loss (Fonseca et al., 2015).

The use of chemical products to combat phytopathogenic microorganisms is very common in farming practices. However, some problems have been reported. Environmental contamination, increased production costs, and the pathogens' resistance to chemicals are the current challenges being faced. The problem of resistance has worsened with the need for higher doses of crop protection products. These products do not meet export criteria, thus affecting economic development in addition to their environmental and biological impacts (Joshi, 2013; Rizvi et al., 2014).

In order to minimize these impacts, the use of alternative natural products is being studied. Plant extracts and essential oils (EOs) have shown efficacy in the control of plant pathogens, whether resistant or not to common chemical products (Fonseca et al., 2015).

Ocimum gratissimum L. belongs to the Lamiaceae family and is commonly found in Africa, Asia, and South America. The Ocimum genus contains approximately 30 known species that are distributed across the warmest regions of the planet. This plant genus produces an EO that is valued by the perfumery, cosmetic, pharmaceutical, and food industries (Pandey et al., 2014). O. gratissimum is popularly known as clove basil, African basil, and in Hawaii as wild basil. It is characterized by a woody stem at the base and reaching up to $3 \mathrm{~m}$ in height. It has ovate leaves ranging from 5 to $13 \mathrm{~cm}$ in length and 3 to $9 \mathrm{~cm}$ in width, with petioles 1 to $6 \mathrm{~cm}$ in length. Its flowers are arranged in simple or branched bunches, ranging from 5 to 30 $\mathrm{cm}$ in length (Matasyoh et al., 2007).

The species is commonly used as a condiment in the food industry and as a medicinal plant, given its anti-inflammatory, analgesic, hepatoprotective, anti-mutagenic, antihypertensive, and anticarcinogenic effects. Its antinociceptive, intestinal motility antagonistic, antibacterial, and antifungal activities have been proven in previous study (Gontijo et al., 2014).

Genetics and Molecular Research 16 (1): gmr16019542 
Its pharmacological properties are associated with its $\mathrm{EO}$, which is concentrated mainly in the stem, leaves, and flowers, and is composed mainly of eugenol, linalool, camphor, and thymol (Matasyoh et al., 2007; Pandey et al., 2014). In addition to EO, the plant also produces saponins, flavonoids, tannins, and cardiac glycosides, as products of their secondary metabolism (Gontijo et al., 2014). Recent studies have demonstrated that clove basil EO has inhibitory effect on the growth of some fungi such as Penicillium and Rhizoctonia (Philippe et al., 2012; Sethi et al., 2013; Rizvi et al., 2014).

Therefore, this study aimed at assessing the microbial activity, yield, and composition of the EO of open-field cultivated clove basil.

\section{MATERIAL AND METHODS}

\section{Experimental procedure and soil analysis}

The clove basil plants (voucher specimen deposited in the Paranaense University Educational Herbarium; No. 1900) cultivated on a $30-\mathrm{m}^{2}$ garden bed located in the Medicinal Herbarium of the Educational Faculty of Dois Vizinhos (FAED) - UNISEP (União de Ensino do Sudoeste do Paraná, Paraná State - Brazil), at coordinates $25^{\circ} 46^{\prime} 31.04^{\prime \prime S}$ and 5302'56.78"WO.

The seeds were purchased from a commercial retail vendor. They were disinfected with $70 \%$ alcohol solution for $15 \mathrm{~min}$. Then, they were placed in boxes containing substrate for seedlings and cultivated up to $15 \mathrm{~cm}$ in height for transplantation into the garden bed.

Soil samples $( \pm 500 \mathrm{~g})$ from the Medicinal Herbarium were collected at $0-10 \mathrm{~cm}$ depth from five different points of the bed and submitted for analysis. The samples were placed in plastic bags and stored in a refrigerator $\left(4^{\circ} \mathrm{C}\right)$ until the lab analysis, which was performed in duplicate.

A composite soil sample was sent to the Solo Fértil laboratory. All analyses followed the standards recommended by CELA (State Commission of Agronomic Analysis Laboratories in Paraná State).

\section{Essential oil}

The clove basil was harvested in July 2015, during the morning hours of 7-8 am. The fresh aerial parts of the clove basil plants were subjected to hydrodistillation in a modified Clevenger apparatus for $3 \mathrm{~h}$. Extracts were obtained in triplicate for each treatment. The EO was removed from the device with hexane, filtered with anhydrous $\mathrm{Na}_{2} \mathrm{SO}_{4}$, stored in amber flasks, and refrigerated in open flasks until total evaporation of the hexane. Then, each extract was weighed to calculate the EO content (weight/weight \%).

\section{Chemical identification of essential oil via gas chromatography-mass spectrometry analysis}

The EO analysis was carried out in a gas chromatographic system (Agilent $7890 \mathrm{~B}$ ) (Agilent Technologies, Santa Clara, CA, USA), coupled to a mass spectrometer (Agilent 5977 A) equipped with an Agilent HP-5MS capillary column (30 m x $0.250 \mathrm{~mm} \times 0.25 \mu \mathrm{m})$. The following conditions were used: injector temperature of $250^{\circ} \mathrm{C}$, injection volume $1 \mu \mathrm{L}$ at a ratio of $1: 2$ (split mode), and initial column temperature of $40^{\circ} \mathrm{C}$ and heated gradually to $300^{\circ} \mathrm{C}$ at

Genetics and Molecular Research 16 (1): gmr16019542 
a rate of $8^{\circ} \mathrm{C} / \mathrm{min}$. The carrier gas (helium) flow was set at $1 \mathrm{~mL} / \mathrm{min}$. The temperatures of the transfer line, ion source, and quadrupole were $250^{\circ}, 230^{\circ}$, and $150^{\circ} \mathrm{C}$, respectively. The mass spectra were obtained in a range of 40-500 ( $\mathrm{m} / \mathrm{z})$ provided through scan mode with solvent delay time of $3 \mathrm{~min}$, and the compounds were identified based on comparison of their retention indices (RI) obtained using various n-alkanes (C8-C25), according to Adams (2012).

\section{Fungal isolates and determination of the minimum inhibitory concentration}

The minimal inhibitory concentrations (MIC) of EO were determined for the following isolates: Fusarium oxysporum f. sp. tracheiphilum (CMM-0033), F. oxysporum f. sp. cubense (CMM-0813 and CMM-2819), F. oxysporum f. sp. lycopersici (CMM-1104), F. solani (CMM3828), Rhizoctonia solani (CMM-3274), and Macrophomina phaseolina (CMM-2715, CMM3875, CMM-3615, and CMM-3650). All isolates were provided from culture collection of pathogenic fungi at Federal Rural University of Pernambuco (UFRPe), Brazil. A 40,000 $\mu \mathrm{g} /$ $\mathrm{mL}$ EO solution diluted with $2 \%$ polysorbate 80 in Sabouraud broth with $2 \%$ glucose was prepared to treat the isolates. The culture medium $(100 \mu \mathrm{L})$ was distributed into wells of a 96 microdilution plate, and then $200 \mu \mathrm{L}$ EO solution was added to the second well. Following homogenization, the solution was transferred to the third well, and so on until the tenth well. Thus, the final concentrations obtained after serial dilution were: $40,20,10,5,2.5,1.25,0.625$, and $0.312 \mathrm{mg} / \mathrm{mL}$. A microbial suspension was prepared in saline with turbidity equivalent to the tube 0.5 of the McFarland scale ( $1 \times 10^{6} \mathrm{UFC}$-Unit forming colony/mL). Next, the 1:100 fungal suspension was diluted with Sabouraud broth to obtain $1 \times 10^{4} \mathrm{UFC} / \mathrm{mL}$ as inoculums. Similarly, the 1:50 fungal suspension was diluted 1:20 in Mueller-Hinton broth modified for fungi to yield $1 \times 10^{5} \mathrm{UFC} / \mathrm{mL}$ as inoculums. The suspensions $(100 \mu \mathrm{L})$ were inoculated in triplicate to each well containing the EO concentrations. The control for sterility was in well number 1 . The toxicity control was $2 \%$ polysorbate 80 in culture medium in well number 11 . The growth control was in well number 12 where the microbial suspension was inoculated into the culture medium. Microplates were incubated at $37^{\circ} \mathrm{C}$ for $48 \mathrm{~h}$ under aerobic conditions. The lowest concentration of EO causing complete inhibition of growth (CLSI, 2008) was reported. The same procedure was performed with fractions of the EO, using an initial solution of $20 \mathrm{mg} / \mathrm{mL}$. A solution of commercial fungicide ketoconazole (Zorkapharma ${ }^{\mathrm{TM}}$ ) was used as positive control (1-4000 mg/mL) (Linde et al., 2016).

\section{RESULTS AND DISCUSSION}

\section{Characteristics of growth field and clove basil essential oil}

The soil where the clove basil plants were cultivated was classified as dystrophic haplustox (red latosol) (LVd19 - Oxisol) (EMBRAPA - Empresa Brasileira de Pesquisa Agropecuária, 2013) and its chemical characteristics are described in Table 1.

It was observed that the assessed parameters diverged from the reference values (Table 1). The amount of organic matter, represented by the carbon rate, exceeded the reference standard. This was explained by Freitas et al. (2015) who affirmed that preparing and cultivating soil for crops cause mineralization of the organic matter owing to the accumulation of plant debris. In addition, the authors associate an increased cation exchange capacity (CEC) with an increased accumulation of organic matter, which explains the results found in this study.

Genetics and Molecular Research 16 (1): gmr16019542 
Table 1. Chemical properties of the soil used in the experimental area.

\begin{tabular}{l|c|c|c|c|c|c|c|c|c|c|c|c|c}
\hline & $\mathrm{pH}\left(\mathrm{CaCl}_{2}\right)$ & $\begin{array}{c}\mathrm{P} \\
\mathrm{mg} / \mathrm{dm}^{3}\end{array}$ & \multirow{2}{*}{$\begin{array}{c}\mathrm{C} \\
\mathrm{g} / \mathrm{dm}^{3}\end{array}$} & $\mathrm{Al}^{3+}$ & $\mathrm{H}^{+}+\mathrm{Al}^{3+}$ & $\mathrm{Ca}^{2+}$ & $\mathrm{Mg}^{2+}$ & $\mathrm{K}^{+}$ & $\mathrm{SB}$ & $\mathrm{CEC}$ & \multicolumn{2}{c|}{$\begin{array}{c}\mathrm{V} \\
\mathrm{Cmol}_{\mathrm{c}} / \mathrm{dm}^{3}\end{array}$} \\
\hline Soil $^{\mathrm{a}}$ & 6.47 & 16.42 & 17.53 & 0.00 & 2.36 & 7.50 & 3.63 & 0.26 & 11.38 & 13.74 & 82.83 \\
\hline Reference $^{\mathrm{b}}$ & $3.8-6.6$ & $16-24$ & $0.8-15.9$ & - & $0.6-5.0$ & $0.3-7.2$ & $0.3-3.3$ & $0.1-0.7$ & - & $2.2-12.5$ & - \\
\hline
\end{tabular}

${ }^{a}$ Methods: C: dichromate/colorimetric; P and K extracted using Mehlich-I; and $\mathrm{Ca}, \mathrm{Mg}$, and $\mathrm{Al}$ extracted using $1 \mathrm{M}$ KCl. 'Source: Sambatti et al. (2003). CEC: cation exchange capacity; SB: sum of bases; V: base saturation.

In this study, the EO content in the extract of fresh leaves of clove basil plants was $0.18 \pm 0.04 \%$. Fokou et al. (2014) found similar EO content (0.19\%) in extracts of clove basil plants cultivated in Cameroon. Aguiar et al. (2015) obtained 0.45\% EO yield, when the plants were cultivated in the Crato region of Ceará, Brazil.

Borges et al. (2012) compared the EO yield from fresh and dry leaves of clove basil plants. The fresh leaves yielded $0.13 \%$ EO content, similar to this study. The dry leaves produced a higher $1.02 \%$ yield. Therefore, it is important to indicate the extraction method, plant age, and moisture content in order to explain the variable EO content in different studies (Ade-Ademilua et al., 2013; Lermen et al., 2015; Urcoviche et al., 2015; Linde et al., 2016).

In a comparative study carried out in Nigeria, Ade-Ademilua et al. (2013) compared different methods of cultivation and determined EO contents of the clove basil plants. The plants were cultivated in shade or sunlight, and with or without water stress. Significant differences were found among the EO yields. Plants cultivated in sunlight and subjected to water stress produced $0.2 \%$ EO. In contrast, plants cultivated in shade but also subjected to water stress produced $1 \% \mathrm{EO}$. This result indicates that growing conditions are factors that directly influence the $\mathrm{EO}$ content of plants.

In the present study, 30 chemical compounds were identified in the clove basil EO (Table 2). Oxygenated monoterpenes (72.4\%), with linalool (32.9\%) and 1,8 cineole $(21.9 \%)$ as the major compounds, were the most predominant compounds identified. In another study by Kpoviesse et al. (2014), they reported 32.96-35.43\% of oxygenated monoterpenes in the EO of $O$. gratissimum cultivated in Benin, which is only half the quantity found in this study. Adjou et al. (2012) identified 31 chemical compounds in the clove basil EO extracted from fresh leaves. The gas chromatography-mass spectrometry (GC-MS) analysis also indicated different groups of terpenes. The major chemical compounds found in their study were thymol $(26 \%)$, followed by $\gamma$-terpinene $(20 \%)$ and p-cymene $(17.6 \%)$.

Stefan et al. (2013) analyzed the chemical composition of EO from three plants of the Ocimum genus cultivated in Romania. Linalool was also the major compound found in the EO of $O$. gratissimum.

Linalool is an acyclic monoterpene tertiary alcohol, widely used in the cosmetic industry due to its fragrance properties. In addition to fragrance properties, studies have proven its biological activities as an antinociceptive, antileishmanial, and antimicrobial agent (Camargo and Vasconcelos, 2014).

Nguemtchouin et al. (2013) found 32 compounds in the EO extracted from fresh leaves of clove basil plants. In this case, the major compound was thymol (53.9\%), followed by $\gamma$-terpinene (17.8\%). The authors also reported five chemotypes recently identified in clove basil plants, which include eugenol, thymol, citral, linalool, and ethyl cinnamate as major compounds.

According to Kpoviessi et al. (2014), divergence can occur with respect to the chemical composition of EO, and can be associated with various factors, including the vegetative phase

Genetics and Molecular Research 16 (1): gmr16019542 
Table 2. Chemical composition of the essential oil obtained from the leaves of Ocimum gratissimum.

\begin{tabular}{|c|c|c|c|c|}
\hline Peak & Compounds & Area $(\%)$ & ${ }^{\mathrm{b}} \mathrm{RI}$ calculated & Methods of identification \\
\hline 1 & $\alpha$-Pinene & 0.53 & 937 & $\mathrm{a}, \mathrm{b}$ \\
\hline 2 & Camphene & 0.46 & 952 & $\mathrm{a}, \mathrm{b}$ \\
\hline 3 & Sabinene & 0.60 & 979 & $a, b$ \\
\hline 4 & $\beta$-Pinene & 1.25 & 985 & $\mathrm{a}, \mathrm{b}$ \\
\hline 5 & Myrcene & 0.83 & 992 & $\mathrm{a}, \mathrm{b}$ \\
\hline 6 & $\alpha$-Terpinene & $\mathrm{t}$ & 1019 & $a, b$ \\
\hline 7 & Limonene & 1.15 & 1031 & $a, b$ \\
\hline 8 & 1,8-Cineole & 21.91 & 1034 & $\mathrm{a}, \mathrm{b}$ \\
\hline 9 & cis-Sabinene hydrato & $\mathrm{t}$ & 1069 & $\mathrm{a}, \mathrm{b}$ \\
\hline 10 & Fenchone & 1.34 & 1089 & $\mathrm{a}, \mathrm{b}$ \\
\hline 11 & Linalool & 32.95 & 1101 & $\mathrm{a}, \mathrm{b}$ \\
\hline 12 & Camphor & 11.97 & 1147 & $\mathrm{a}, \mathrm{b}$ \\
\hline 13 & $\delta$-Terpineole & $\mathrm{t}$ & 1168 & $a, b$ \\
\hline 14 & Terpineol 4 & 0.79 & 1188 & $\mathrm{a}, \mathrm{b}$ \\
\hline 15 & $\alpha$-Terpineole & 3.36 & 1190 & $\mathrm{a}, \mathrm{b}$ \\
\hline 16 & Eugenol & 7.42 & 1359 & $\mathrm{a}, \mathrm{b}$ \\
\hline 17 & $\alpha$-Copaene & $\mathrm{t}$ & 1376 & $\mathrm{a}, \mathrm{b}$ \\
\hline 18 & $\beta$-Bourbenene & $\mathrm{t}$ & 1384 & $\mathrm{a}, \mathrm{b}$ \\
\hline 19 & $\beta$-Elemene & 0.93 & 1391 & $\mathrm{a}, \mathrm{b}$ \\
\hline 20 & trans-Caryophyllene & 1.68 & 1418 & $\mathrm{a}, \mathrm{b}$ \\
\hline 21 & $\alpha$-Bergamotene & 1.07 & 1436 & $\mathrm{a}, \mathrm{b}$ \\
\hline 22 & $\alpha$-Humulene & $\mathrm{t}$ & 1453 & $\mathrm{a}, \mathrm{b}$ \\
\hline 23 & Epi-bicyclosesquiphelandrene & $\mathrm{t}$ & 1462 & $\mathrm{a}, \mathrm{b}$ \\
\hline 24 & Germacrene D & 4.76 & 1480 & $\mathrm{a}, \mathrm{b}$ \\
\hline 25 & Bicyclogermacrene & $\mathrm{t}$ & 1494 & $\mathrm{a}, \mathrm{b}$ \\
\hline 26 & $\delta$-Guaiene & $\mathrm{t}$ & 1504 & $\mathrm{a}, \mathrm{b}$ \\
\hline 27 & $\gamma$-Cadiene & 1.05 & 1512 & $\mathrm{a}, \mathrm{b}$ \\
\hline 28 & $\delta$-Cadiene & $\mathrm{t}$ & 1523 & $\mathrm{a}, \mathrm{b}$ \\
\hline 29 & Cadina 1,4-diene & 0.67 & 1613 & $\mathrm{a}, \mathrm{b}$ \\
\hline 30 & $\alpha$-Cadinol & 5.18 & 1640 & $\mathrm{a}, \mathrm{b}$ \\
\hline \multicolumn{5}{|c|}{ Compound groups (\%) } \\
\hline \multicolumn{2}{|c|}{ Monoterpene hydrocarbons } & 4.82 & & \\
\hline \multicolumn{2}{|c|}{ Oxygenated monoterpenes } & 72.30 & & \\
\hline \multicolumn{2}{|c|}{ Sesquiterpene hydrocarbons } & 10.16 & & \\
\hline \multicolumn{2}{|c|}{ Oxygenated sesquiterpenes } & 5.18 & & \\
\hline \multicolumn{2}{|c|}{ Phenylpropanoids } & 7.42 & & \\
\hline \multicolumn{2}{|c|}{ Total identified compounds (\%) } & 99.87 & & \\
\hline
\end{tabular}

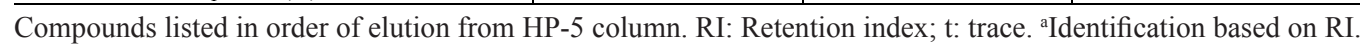
${ }^{b}$ Identification based on comparison of mass spectra.

of the plant. In their study, the major compounds of the clove basil EO were cymene, before flowering, and thymol, after flowering.

Edaphoclimatic factors as well as methods of obtaining EOs can directly influence the EO composition. It is known that the soil composition, both chemical and organic, is directly connected to the EO composition owing to the variability of macro- and micro-nutrients available to the plants. Factors such as climate, water availability, crop season, geographic location, and incidence of pathogens can influence the production of chemical compounds of EOs (Ade-Ademilua et al., 2013; Lermen et al., 2015; Urcoviche et al., 2015).

\section{Minimum inhibitory concentration}

The antifungal effect of the clove basil EO on the phytopathogenic fungi isolates was expressed in MICs (Table 3). Theses isolates were chosen due may cause substantially 
decrease in yield on several crops, such as, beans, soybeans, tomato, banana, papaya, melon and etc. Some of OE presents antifungal traits, and maybe be used in agriculture, reducing agrochemicals applications, bring to the consumers food more sustainable and with more quality. The clove basil EO had an antifungal effect on all tested isolates; however, the MIC values varied. The antifungal effect was more potent on 2 of the 10 tested fungi, F. oxysporum f. sp. lycopersici (CMM-1104) and $R$. solani CMM-3274), and both were sensitive at 31.25 $\mu \mathrm{g} / \mathrm{mL}$ MIC (Table 3).

Table 3. Minimum inhibitory concentration (MIC) of essential oil of Ocimum gratissimum.

\begin{tabular}{l|c}
\hline Phytopathogenic fungi & $\mathrm{MIC}(\mu \mathrm{g} / \mathrm{mL})$ \\
\hline Fusarium oxysporum f. sp. tracheiphilum (CMM-0033)* & 62.5 \\
\hline F. oxysporum f. sp. cubense (CMM-0813) & 62.5 \\
\hline F. oxysporum f. sp. cubense (CMM-2819) & 62.5 \\
\hline F. oxysporum f. sp. lycopersici (CMM-1104) & 31.25 \\
\hline F. solani (CMM-3828) & 62.5 \\
\hline Rhizoctonia solani (CMM-3274) & 31.25 \\
\hline Macrophomina phaseolina (CMM-2715) & 125.0 \\
\hline M. phaseolina (CMM-3875) & 125.0 \\
\hline M. phaseolina (CMM-3615) & 62.5 \\
\hline M. phaseolina (CMM-3650) & 62.5 \\
\hline Positive control - Ketoconazole & 500.0 \\
\hline
\end{tabular}

*CMM: Code used for culture collection of pathogenic fungi at Federal Rural University of Pernambuco (UFRPE).

This antifungal effect can be explained by the chemical composition of the EO. Monoterpenes and sesquiterpenes with aromatic rings and phenol groups are capable of forming hydrogen bonds with the active sites of target enzymes, and is the main cause for the antimicrobial effects of the EO. Other compounds such as alcohols, aldehydes, and esters also contribute to the antimicrobial activity (Belletti et al., 2004). The two major compounds found in the clove basil EO, linalool and 1,8-cineole, have antimicrobial activity as reported earlier in the literature (Pandey et al., 2014). Linalool can cause protein denaturation and dehydration of vegetative cells, which causes the death of microorganisms in contact with the EO. This mechanism is comparable to that of chlorhexidine, an important antimicrobial agent (Camargo and Vasconcelos, 2014). Pattnaik et al. (1997) analyzed the antifungal action of oxygenated monoterpenes and found that linalool showed an inhibitory action on Candida albicans at 200 $\mu \mathrm{g} / \mathrm{mL}$ MIC, while this yeast was resistant to 1,8 -cineole for MIC values up to $5000 \mu \mathrm{g} / \mathrm{mL}$. Adegoke et al. (2000) assessed the microbial activity of 1,8-cineole on C. tropicalis and found inhibitory action at $156 \mu \mathrm{g} / \mathrm{mL}$ MIC.

In this study, the antifungal effect of the EO can be considered very potent against all tested isolates, surpassing even that of the positive control ketoconazole at $500 \mu \mathrm{g} / \mathrm{mL}$ MIC (Table 3). According to Duarte et al. (2005), MIC values up to $500 \mu \mathrm{g} / \mathrm{mL}$ of the tested substance can be considered highly effective. Considering this reasoning, all phytopathogenic fungi tested can be considered highly susceptible to the EO of $O$. gratissimum. This finding is very important for further studies with $\mathrm{EO}$ of $O$. gratissimum that can lead to less use of chemical fungicides in agriculture, and produce foods with better quality and that are more sustainable.

Sethi et al. (2013) tested the antimicrobial activity of various EOs from the Ocimum genus, all cultivated in the Uttarakhand region, India, on $R$. solani and observed that MIC of EO extracted from $O$. gratissimum was $62.5 \mu \mathrm{g} / \mathrm{mL}$, twice the value found in this study $(31.25 \mu \mathrm{g} / \mathrm{mL})$.

Philippe et al. (2012) tested the antifungal effect of the EO extracted from fresh

Genetics and Molecular Research 16 (1): gmr16019542 
leaves of clove basil cultivated in Benin. The studied isolates were from the genera Fusarium, Penicillium, and Aspergillus. The authors observed total inhibition of all fungal isolates at 1000 $\mu \mathrm{g} / \mathrm{mL}$ MIC, but with decreasing concentration, the effectiveness declined proportionally. For the lowest MIC $(200 \mu \mathrm{g} / \mathrm{mL})$, they observed that the fungal inhibition was less than $50 \%$. The authors also determined the chemical composition of the oil and observed that the major compound was thymol (28.1\%), followed by $\gamma$-terpinene $(21.3 \%)$.

Joshi (2013) demonstrated that the MIC of the clove basil EO for Aspergillus and Penicillium was less than $1000 \mu \mathrm{g} / \mathrm{mL}$. This result affirms the effectiveness of the EO as an inhibitor of the phytopathogenic fungi.

Rizvi et al. (2014) studied the chemical composition and the antifungal activity of the clove basil EO from India. The major compound found in the oil was eugenol (77.8\%). The authors also assessed the antifungal effect of the EO on two species of Penicillium causing diseases in apple fruits, and observed that both species were inhibited at $500 \mu \mathrm{g} / \mathrm{mL} \mathrm{MIC}$. This also confirms yours findings in the present study with 10 others phytopathogens fungal.

\section{CONCLUSIONS}

An effective antimicrobial activity on the 10 tested phytopathogens was observed. The MIC of the clove basil EO was equal to or less than $125 \mu \mathrm{g} / \mathrm{mL}$ for the tested isolates. Therefore, it can be concluded that clove basil EO is highly effective as an antifungal agent, showing great potential as an alternative for the control of diseases caused by phytopathogenic fungi.

The EO content of the clove basil leaves was found to be $0.18 \%$. Thirty compounds of the EO were detected via GC-MS, with the predominance of oxygenated monoterpenes. The major chemical compound found in the oil was linalool, followed by 1,8-cineole.

\section{Conflicts of interest}

The authors declare no conflict of interest.

\section{ACKNOWLEDGMENTS}

The authors thank UNIPAR for financial support. Caroline Lermen thanks for the scholarship from Coordenação de Aperfeiçoamento de Pessoal de Nível Superior (CAPES). Odair Alberton thanks Conselho Nacional de Desenvolvimento Científico e Tecnológico - CNPq for a research fellowship. The authors also thank the Universidade Federal Rural de Pernambuco - UFRPE, especially Dr. Sami J. Michereff for providing the isolates of phytopathogenic fungi for this study.

\section{REFERENCES}

Adams RP (2012). Identification of essential oil components by gas chromatography/mass spectrometry, 4th edition. Allured Publishing Corporation, Carol Stream.

Ade-Ademilua EO, Obi HO and Craker LE (2013). Growth and essential oil yield of African basil, Ocimum gratissimum, under light and water stress. J. Med. Act. Pl. 1: 143-149. http://dx.doi.org/10.7275/R59W0CD7

Adjou ES, Kouton S, Dahouenon-Ahoussi E, Soumanou MM, et al. (2012). Effect of essential oil from fresh leaves of Ocimum gratissimum L. on mycoflora during storage of peanuts in Benin. Mycotoxin Res. 29: 29-38. http://dx.doi. org/10.1007/s12550-012-0150-y.

Genetics and Molecular Research 16 (1): gmr16019542 
Aguiar JJS, Sousa CPB, Araruna MKA, Silva MKN, et al. (2015). Antibacterial and modifying-antibiotic activities of the essential oils of Ocimum gratissimum L. and Plectranthus amboinicus L. Eur. J. Integr. Med. 7: 151-156 http:// dx.doi.org/10.1016/j.eujim.2014.10.005.

Adegoke GO, Iwahashi H, Komatsu Y, Obuchi K, et al. (2000). Inhibition of food spoilage yeasts and aflatoxigenic molds by monoterpenes of the spice Aframomum danielli. Flavour Fragrance J. 15: 147-150 http://dx.doi.org/10.1002/10991026(200005/06)15:3<147::AID-FFJ883>3.0.CO;2-0.

Belletti N, Ndagijimana M, Sisto C, Guerzoni ME, et al. (2004). Evaluation of the antimicrobial activity of citrus essences on Saccharomyces cerevisiae. J. Agric. Food Chem. 52: 6932-6938 http://dx.doi.org/10.1021/jf049444v.

Borges AM, Pereira J, Cardoso MG, Alves JA, et al. (2012). Determinação de óleos essenciais de alfavaca (Ocimum gratissimum L.), orégano (Origanum vulgare L.) e tomilho (Thymus vulgaris L.). Rev. Bras. Pl. Med. 14: 656-665 http://dx.doi.org/10.1590/S1516-05722012000400013.

Camargo SB and Vasconcelos DFSA (2014). Atividades biológicas de Linalol: conceitos atuais e possibilidades futuras deste monoterpeno. Rev. Cienc. Med. Biol. 13: 381-387 10.9771/cmbio.v13i3.12949.

CLSI (2008). Clinical and Laboratory Standards Institute - reference method for broth dilution antifungal susceptibility testing of yeasts; approved standard, 3ed. 940 West Valley Road, Suite 1400, Wayne, Pensylvania 19087-1898, USA, (CLSI document M27-A3).

Duarte MCT, Figueira GM, Sartoratto A, Rehder VLG, et al. (2005). Anti-Candida activity of Brazilian medicinal plants. J. Ethnopharmacol. 97: 305-311 http://dx.doi.org/10.1016/j.jep.2004.11.016.

EMBRAPA - Empresa Brasileira de Pesquisa Agropecuária (2013). Sistema brasileiro de classificação de solos. 3. ed. Brasília.

Fokou JBH, Dongmo PMJ, Boyom FF, Menkem EZ, et al. (2014). Antioxidant and antifungal activities of the essential oils of Ocimum gratissimum from Yaoundé and Dschang (Cameroon). J. Pharm. Pharmacol. 2: 257-268.

Fonseca MC, Lehner MS, Gonçalves MG, Paula-Júnior TJ, et al. (2015). Potencial de óleos essenciais de plantas medicinais no controle de fitopatógenos. Rev. Bras. Pl. Med. 17: 45-50 http://dx.doi.org/10.1590/1983-084X/12 170.

Freitas L, Cassagrande JC, Oliveira IA, Campos MCC, et al. (2015). Técnicas multivariadas na avaliação de atributos de um Latossolo vermelho submetido a diferentes manejos. Agraria 10: 17-26 http://dx.doi.org/10.5039/agraria. v10i1a3928.

Gontijo DC, Fietto LC and Leite JPV (2014). Avaliação fitoquímica e atividade antioxidante, antimutagênica e toxicológica do extrato aquoso das folhas de Ocimum gratissimum L. Rev. Bras. Pl. Med. 16: 874-880 http://dx.doi. org/10.1590/1983-084X/12 002.

Joshi RK (2013). Chemical composition, in vitro antimicrobial and antioxidant activities of the essential oils of Ocimum gratissimum, O. sanctum and their major constituents. Indian J. Pharm. Sci. 75: 457-462 http://dx.doi. org/10.4103/0250-474X.119834.

Kpoviessi BGHK, Kpoviessi SD, Yayi Ladekan E, Gbaguidi F, et al. (2014). In vitro antitrypanosomal and antiplasmodial activities of crude extracts and essential oils of Ocimum gratissimum Linn from Benin and influence of vegetative stage. J. Ethnopharmacol. 155: 1417-1423 http://dx.doi.org/10.1016/j.jep.2014.07.014.

Lermen C, Morelli F, Gazim ZC, da Silva AP, et al. (2015). Essential oil content and chemical composition of Cymbopogon citratus inoculated with arbuscular mycorrhizal fungi under different levels of lead. Ind. Crops Prod. 76: 734-738 http://dx.doi.org/10.1016/j.indcrop.2015.07.009.

Linde GA, Gazim ZC, Cardoso BK, Jorge LF, et al. (2016). Antifungal and antibacterial activities of Petroselinum crispum essential oil. Genet. Mol. Res. 15: 3 http://dx.doi.org/10.4238/gmr.15038538.

Matasyoh LG, Matasyoh JC, Wachira FN, Kinyua MG, et al. (2007). Chemical composition and antimicrobial activity of the essential oil of Ocimum gratissimum L. growing in Eastern Kenya. Afr. J. Biotechnol. 6: 760-765.

Nguemtchouin MGM, Ngassoum MB, Chalier P, Kamga R, et al. (2013). Ocimum gratissimum essential oil and modified montmorillonite clay, a means of controlling insect pests in stored products. J. Stored Prod. Res. 52: 57-62 http:// dx.doi.org/10.1016/j.jspr.2012.09.006.

Pandey AK, Singh P and Tripathi NN (2014). Chemistry and bioactivities of essential oils of some Ocimum species: an overview. Asian Pac. J. Trop. Biomed. 4: 682-694 http://dx.doi.org/10.12980/APJTB.4.2014C77.

Pattnaik S, Subramanyam VR, Bapaji M and Kole CR (1997). Antibacterial and antifungal activity of aromatic constituents of essential oils. Microbios 89: 39-46.

Philippe S, Souaïbou F, Paulin A, Issaka Y, et al. (2012). In vitro Antifungal activities of essential oils extracted from fresh leaves of Cinnamomum zeylanicum and Ocimum gratissimum against foodborne pathogens for their use as traditional cheese wagashi conservatives. Res. J. Recent Sci. 1: 67-73.

Rizvi AH, Khan MMAA, Verma PC and Saxena G (2014). Biochemical activity of Ocimum gratissimum essential oil against fruit-rotting fungi Penicillium expansum and Penicillium digitatum. In: Microbial Diversity and Biotechnology

Genetics and Molecular Research 16 (1): gmr16019542 
in Food Security. Springer, India, 343-348.

Sambatti JA, Souza IG, Junior., Costa ACS and Tormena CA (2003). Estimativa da acidez potencial pelo método do pH SMP em solos da formação Caiuá - Noroeste do estado do Paraná. R. Bras. Ci. Solo 27: 257-264. http://dx.doi. org $/ 10.1590 / \mathrm{S} 0100-06832003000200006$

Sethi S, Prakash O, Chandra M, Punetha H, et al. (2013). Antifungal activity of essential oils of some Ocimum species collected from different locations of Uttarakhand. Indian J. Nat. Prod. Resour. 4: 392-397.

Stefan M, Zamfirache M, Padurariu C, Trută E, et al. (2013). The composition and antibacterial activity of essential oils in three Ocimum species growing in Romania. Cent. Eur. J. Biol. 8: 600-608 10.2478/s11535-013-0171-8.

Urcoviche RC, Gazim ZC, Dragunski DC, Barcellos FG, et al. (2015). Plant growth and essential oil content of Mentha crispa inoculated with arbuscular mycorrhizal fungi under different levels of phosphorus. Ind. Crops Prod. 67: 103107 http://dx.doi.org/10.1016/j.indcrop.2015.01.016.

Genetics and Molecular Research 16 (1): gmr16019542 